\title{
Recent Technology Advancement of ECUST Gasification Process
}

\author{
Haifeng L, Gong X*, Guangsuo Y, Wang F, Haifeng L, Wang Y and Xueli Chen \\ Shanghai Engineering Research Center of Coal Gasification, East China University of Science and Technology, China
}

Submission: April 20, 2017; Published: June 30, 2017

*Corresponding author: Xin Gong, Key Laboratory of Coal Gasification and Energy Chemical Engineering of Ministry of Education, Shanghai Engineering Research Center of Coal Gasification, East China University of Science and Technology, Shanghai 200237, PR China,

Email: luhf@ecust.edu.cn

\section{Opinion}

Institute of Clean Coal Technology (ICCT) in East China University of Science and Technology (ECUST), located in Shanghai, is focused on fundamental research to address the engineering problems of coal gasification and aimed to develop large scale and high efficiency coal gasification technology meeting demand of modern advanced energy conversion. The institute built in 1995, has developed Opposed Multi-Burner (OMB) Coal Water Slurry (CWS) Gasification technology and Dry Coal Gasification technology with completely owned intellectual property.

OMB CWS gasification, the acknowledged state of the art gasification technology, has been developed by ECUST and Yanking Group. This gasification process adopts an entrained flow OMB gasifier to produce syngas that mainly consists of carbon monoxide and hydrogen using a CWS and pure oxygen under high pressure and high temperature operating conditions. With many technical advantages, gasification efficiency of the OMB CWS gasification is very high, and the carbon conversion is normally higher than $98.5 \%$. Up to now, OMB CWS gasification technology has been licensed on 43 projects for a total of 118 gasifiers for locations both in China and the United States. OMB CWS gasification technology is superior in many aspects such as gasification performance, process indexes, stability, and reliability and especially in large-scale gasification applications.
The other typical technology is SE gasification technology of pulverized coal which has been developed by Sinopec and ECUST. The SE gasifier is featured with a single burner on the top, and is designed for satisfying the requirement of chemicals production. Employing such technologies as dry feeding of pulverized coal, membrane wall lining and water quench bath process, the gasification technology has many advantages such as wide adaptability of coal, low consumption of raw materials, advantageous performance and low cost in investment and operation. The principal characteristics of the SE gasification process include the classical jet flow field in a confined space, membrane wall lining with the byproduct of saturated steam, multi-functional integrated burner, visual flame system during gasifer start-up, the direct measurement of gasifier temperature, and the automatic control system for the gasifier start-up and operation. The SE coal gasification technology has been successfully demonstrated in Sinopec Yangzi Petrochemical Company Ltd. With 1000 t/d throughput, and has been licensed to Zhong'an Joint Coal Chemical Company Ltd. for 1500 thousand tons Methanol per year with 7 SE gasifiers, and will also be applied in the project of Sinopec's 8 billion SNG in Xinjiang Autonomous Region.
Your next submission with Juniper Publishers will reach you the below assets

- Quality Editorial service

- Swift Peer Review

- Reprints availability

- E-prints Service

- Manuscript Podcast for convenient understanding

- Global attainment for your research

- Manuscript accessibility in different formats

( Pdf, E-pub, Full Text, Audio)

- Unceasing customer service

Track the below URL for one-step submission https://juniperpublishers.com/online-submission.php 